\title{
PATH ANALYSIS ON THE EFFECT OF BIRTHWEIGHT, MATERNAL EDUCATION, STIMULATION, EXCLUSIVE BREASTFEEDING, AND NUTRITIONAL STATUS ON MOTORIC DEVELOPMENT IN CHILDREN AGED 6-24 MONTHS IN BANYUMAS DISTRICT, CENTRAL JAVA
}

\author{
Inggar Ratna Kusuma1,2), Harsono Salimo3) \\ Endang Sutisna Sulaeman ${ }^{4)}$ \\ 1)Faculty of Health Sciences, Muhamamadiyah University Purwokerto \\ 2)Masters Program in Public Health, Sebelas Maret University \\ 3)Department of Pediatrics, Dr. Moewardi Hospital, Surakarta \\ 4)Faculty of Medicine, Sebelas Maret University
}

\begin{abstract}
Background: The first two years of childhood is a sensitive period for growth and development. Motoric skill is one of essential elements in child development. Good command of motoric control helps children to explore their environment and to improve development. This study aimed to determine the effect of birthweight, maternal education, stimulation, exclusive breastfeeding, and nutritional status on motoric development in children aged 6-24 months in Banyumas district, Central Java, using path analysis.
\end{abstract}

Subjects and Method: This was an analytic observational study with retrospective cohort design. This study was conducted at 4 sub-districts (Kembaran, Somagede, Cilongok, and Sumpiuh), Banyumas District, Central Java. A sample of 120 children aged 6-24 months, consisting of 40 children with low birthweight and 80 children with normal birthweight, were selected by fixed exposure sampling. The exogenous variables included birthweight, exclusivebreastfeeding, maternal education, and stimulation. The endogenous variable was nutritional status and motoric development. The data on motoric development was collected by SDIDTK test, while some other variables were collected by questionnaire. The data were analyzed by path analysis.

Results: Motoric development was directly affected by nutritional status $(b=$ $0.12 ; \mathrm{SE}=0.04 ; \mathrm{p}=0.006)$, frequency of stimulation $(\mathrm{b}=0.04 ; \mathrm{SE}=0.01 ; \mathrm{p}=$ 0.005), birthweight $(\mathrm{b}=0.33 ; \mathrm{SE}=0.06 ; \mathrm{p}<0.001)$, and maternal education $(b=0.02 ; S E=0.07 ; p=0.719)$. Nutritional status was affected by exclusive breastfeeding $(b=0.10 ; \mathrm{SE}=0.15 ; \mathrm{p}=0.507)$, maternal education $(b=0.23$; $\mathrm{SE}=0.13 ; \mathrm{p}=0.078)$, and birthweight $(\mathrm{b}=0.38 ; \mathrm{SE}=0.12 ; \mathrm{p}=0.002)$.

Conclusion: Motoric development was directly affected by nutritional status, frequency of stimulation, birthweight, and maternal education. Motoric development was indirectly affected by exclusive breastfeeding, maternal education, and birthweight.

Keywords: birthweight, exclusive breastfeeding, stimulation, maternal education, nutritional status, motoric development

Correspondence: Inggar Ratna Kusuma. Faculty of Health Sciences, Muhamamadiyah University Purwokerto, Purwokerto, Central Java.

Email: inggarratna@gmail.com. Mobile: +628562553967. 